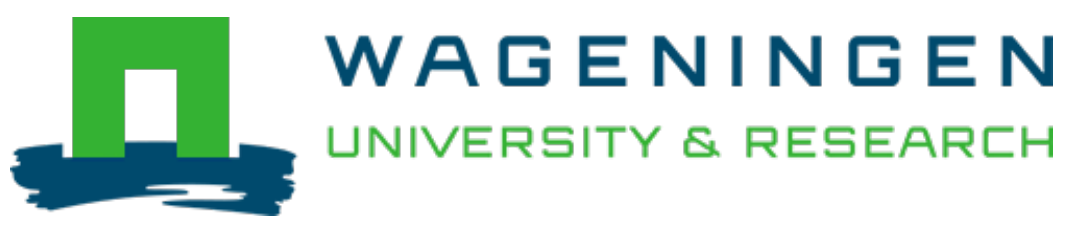

\title{
Fungal interactions in food fermentations
}

Canadian Journal of Botany

Nout, M.J.R.

This publication is made publicly available in the institutional repository of Wageningen University and Research, under the terms of article $25 \mathrm{fa}$ of the Dutch Copyright Act, also known as the Amendment Taverne. This has been done with explicit consent by the author.

Article 25 fa states that the author of a short scientific work funded either wholly or partially by Dutch public funds is entitled to make that work publicly available for no consideration following a reasonable period of time after the work was first published, provided that clear reference is made to the source of the first publication of the work.

This publication is distributed under The Association of Universities in the Netherlands (VSNU) 'Article $25 \mathrm{fa}$ implementation' project. In this project research outputs of researchers employed by Dutch Universities that comply with the legal requirements of Article $25 \mathrm{fa}$ of the Dutch Copyright Act are distributed online and free of cost or other barriers in institutional repositories. Research outputs are distributed six months after their first online publication in the original published version and with proper attribution to the source of the original publication.

You are permitted to download and use the publication for personal purposes. All rights remain with the author(s) and / or copyright owner(s) of this work. Any use of the publication or parts of it other than authorised under article $25 \mathrm{fa}$ of the Dutch Copyright act is prohibited. Wageningen University \& Research and the author(s) of this publication shall not be held responsible or liable for any damages resulting from your (re)use of this publication.

For questions regarding the public availability of this publication please contact openscience.library@wur.nl 


\title{
Fungal interactions in food fermentations
}

\author{
M.J.R. Nout
}

\begin{abstract}
Fermented foods are of importance worldwide. Most are prepared under nonsterile conditions using mixed cultures, either deliberately or unavoidably. Fungal mixed cultures show interactive relations at various levels. In this paper, inhibitory effects among fungi owing to competition, formation of organic acids, toxic proteins, and mycotoxins are discussed. In addition, fungi show inhibitory effects towards bacteria and vice versa, through $\mathrm{pH}$ changes, and excretion of organic acids, antibiotics, peptides, etc. Stimulatory interactions among fungi and between fungi and bacteria relate mainly to carbon and nitrogen metabolism, and they play an important role in the inherent stability of mixedculture systems maintained by enrichment techniques. Better understanding of natural mixed-culture fermentations has evolved into the development of the concept of cocultivation employing compatible microbial strains of complementary metabolic ability. Especially in the area of direct conversion of complex carbohydrates (e.g., starch, inulin, or lignocellulosic matter into ethanol), cocultivation has much to offer. Genetic modification of starter organisms offers opportunities to improve, for example, their ability to degrade substrate with a minimum of catabolite repression, and produce final products of superior quality. This is illustrated by recent recombinant DNA constructs for alcoholic fermentations.
\end{abstract}

Key words: food, fungi, interaction, inhibition, stimulation, cocultivation.

Résumé : Les aliments fermentés sont importants partout dans le monde. La plupart sont préparés sous des conditions non-stériles, en utilisant des cultures mixtes, soit de façon délibérée soit de façon inévitable. Les cultures fongiques mixtes montrent des relations interactives à différents niveaux. Dans sa revue, l'auteur discute les effets inhibiteurs chez les champignons dus à la compétition, à la formation d'acides organiques, d'antibiotiques et de mycotoxines. De plus, les champignons montrent des effets inhibiteurs envers les bactéries et vice versa, par l'intermédiaire de changement du pH et l'excrétion d'acides organiques, d'antibiotiques, de peptides etc. Les interactions de stimulation entre champignons et entre champignons et bactéries sont principalement reliées au métabolisme du carbone et de l'azote, et elles jouent un rôle important dans la stabilité inhérente des systèmes de cultures mixtes maintenues par des techniques d'enrichissement. Une meilleure compréhension des fermentations naturelles mixtes s'est développée avec le développement du concept de co-culture impliquant des souches microbiennes compatibles possédant des dispositions métaboliques complémentaires. Surtout dans les systèmes impliquant la conversion directe des glucides (p. ex., l'amidon, l'inuline ou la matière ligno-cellulosique en éthanol), la co-culture a beaucoup à offrir. La modification génétique des organismes de départ offre des occasions d'améliorer par example, leur capacité à dégrader le substrat avec un minimum de répression catabolique, et des produits finis de qualité supérieure. Ce propos est illustré par la construction récente d'ADN recombinants pour les fermentations éthanoliques.

Mots clés : interaction, inhibition, stimulation, co-culture.

[Traduit par la rédaction]

\section{Fermented foods with functional fungi}

Of the wide range of fungal species, only a few are exploited for the fermentative production of foods and related substances (1). But considering the scale at which these processes are applied worldwide, they are of essential importance to mankind. Owing to economic and process technology factors, most food fermentations are not carried out under aseptic

Received August 15, 1994.

M.J.R. Nout. Department of Food Science, Agricultural University, Bomenweg 2, 6703 HD Wageningen, The Netherlands. conditions with pure cultures. Rather, mixed-culture inocula are deliberately used or, unavoidably, mixed-culture systems develop by enrichment (2). Selected examples of mixed-culture fermented foods with functional fungal flora are listed in Table 1. In principle, the phenomenon of mixed-culture food fermentation has positive and negative aspects. Advantages include complex flavor development, as well as stability for shelf life and consumer safety. Disadvantages stem from the risk of losing the balance between the functional component microorganisms, enabling for example, growth and metabolic activity of undesirable spoilage-causing microorganisms, reduced fermentation efficiency, or even food-borne disease.

Balance in mixed cultures is influenced by a complex range of factors (2) that can be categorized as follows: 
Table 1. A selection of fungal mixed-culture fermented foods.

\begin{tabular}{|c|c|c|c|c|c|}
\hline Molds ${ }^{a}$ & Yeasts $^{a}$ & Bacteria $^{a}$ & Substrate & Product name & Use \\
\hline Amyl. rouxii & $\begin{array}{l}\text { Endonyces spp. } \\
\text { Hyp. burtonii }\end{array}$ & $\begin{array}{l}\text { Ped. pentosaceus } \\
\text { Streptococcus faecalis }\end{array}$ & Uncooked rice & Ragi & Amylolyic starter \\
\hline Amyl. rouxii & $\begin{array}{l}\text { Hyp. burtonii } \\
\text { E. fibuliger }\end{array}$ & $\begin{array}{l}\text { Ped. pentosaceus } \\
\text { Ent. faecalis }\end{array}$ & Cassava & Peuyeum & Semisolid snack \\
\hline $\begin{array}{l}\text { Aspergillus oryzae } \\
\text { A. sojae }\end{array}$ & $\begin{array}{l}\text { Z. rouxii } \\
\text { Candidla /Torulopsis/ versatilis }\end{array}$ & $\begin{array}{l}\text { Ped. halophilus } \\
\text { Ent. faecalis }\end{array}$ & Soya bean + rice/barley & Miso & Flavoring paste \\
\hline $\begin{array}{l}\text { A. oryzae } \\
\text { A. sojae group }\end{array}$ & $\begin{array}{l}\text { Z. rouxii } \\
\text { Z. rouxii [sova] } \\
\text { Z. rouxii [major] } \\
\text { Pichia [Hansenula] spp. } \\
\text { C. [Tlp.] spp. } \\
\text { C. etchellsii } \\
\text { C. versatilis }\end{array}$ & $\begin{array}{l}\text { L. delbrueckii } \\
\text { Ped. halophilus } \\
\text { Ped. damnosus }\end{array}$ & Soya bean + wheat + salt & Soya sauce & Flavoring liquid \\
\hline A. oryzae & $\begin{array}{l}\text { Pi. [H.] anomala } \\
\text { S. cerevisiae }\end{array}$ & $\begin{array}{l}\text { Leuc. mesenteroides var. saké } \\
\text { Lb. saké }\end{array}$ & Rice & Saké & Rice wine \\
\hline P. roqueforti & Y. lipolytica & $\begin{array}{l}\text { Leuconostoc spp. } \\
\text { Lc. lactis } \\
\text { Lc. lactis biovar diacetylactis } \\
\text { Lc. lactis ssp. cremoris }\end{array}$ & Milk curd & Roquefort-type blue-veined cheese & Protein food flavoring \\
\hline$P$. camembertii & $\begin{array}{l}\text { Candida spp. } \\
\text { Kluyveromyces spp. } \\
\text { Saccharomyces spp. } \\
\text { Condida [Tlp./ spp. }\end{array}$ & $\begin{array}{l}\text { Brevibacterium linens } \\
\text { Lc. lactis ssp. cremoris } \\
\text { Lc. lactis }\end{array}$ & Milk curd & $\begin{array}{l}\text { Camembert-type surface-ripened } \\
\text { cheese }\end{array}$ & Protein food flavoring \\
\hline $\begin{array}{l}P . \text { nalgiovense } \\
P . \text { chrysogenum }\end{array}$ & & $\begin{array}{l}\text { Micrococcus spp. } \\
\text { Staphylococcus spp. } \\
\text { Pediococcus spp. } \\
\text { Lactobacillus spp. }\end{array}$ & Meat (sausage) & Salami & Protein food \\
\hline \multirow[t]{4}{*}{$\begin{array}{l}R \text {. oligosporus } \\
R . \text { chinensis } \\
R \text {. oryzae } \\
\text { Mucor indicus }\end{array}$} & $\begin{array}{l}\text { Trichosporon beigelii } \\
\text { Clavispora lusitaniae } \\
\text { C. maltosa } \\
\text { C. intermedia } \\
\text { Y. lipolytica }\end{array}$ & $\begin{array}{l}\text { Klebsiella pneumoniae } \\
\text { Enterobacter cloacae } \\
\text { Lactobacillus spp. }\end{array}$ & Mostly soya beans & Tempe & Protein food \\
\hline & $\begin{array}{l}\text { C. ITlp./ holmii } \\
\text { S. cerevisiae } \\
\text { Pi. saitoi } \\
\text { C. krusei }\end{array}$ & $\begin{array}{l}\text { Lb. plantarum } \\
\text { Lb. fructivorans } \\
\text { Lb. brevis var. lindneri } \\
\text { Lb. sanfrancisco }\end{array}$ & Rye or wheat flour & Sourdough & Bread leaven \\
\hline & $\begin{array}{l}\text { S. cerevisiae } \\
\text { Hsp. guilliermondii } \\
\text { K. apiculata }\end{array}$ & $\begin{array}{l}\text { Leuc. oenos } \\
\text { Ped. acidilactici } \\
\text { Lb. casei }\end{array}$ & Grape juice & Wine & Liquor \\
\hline & $\begin{array}{l}\text { S. cerevisiae } \\
\text { Dekkera [Brettanomyces] spp. }\end{array}$ & $\begin{array}{l}\text { Lactobacillus spp. } \\
\text { Pediococcus spp. }\end{array}$ & Barley, wheat & Lambic-Gueuze & Beer \\
\hline
\end{tabular}

${ }^{a}$ A., Aspergillus; Amyl., Amylomyces; C., Candida; E., Endomyces; Ent., Enterococcus; H., Hansenula; Hsp., Hanseniaspora; Hyp., Hyphopichia; K., Kloeckera; Lb., Lactobacillus Lc., Lactococcus; Leuc., Leuconostoc; P., Penicillium; Ped., Pediococcus; Pi., Pichia; R., Rhizopus; S., Saccharomyces; Tlp., Torulopsis; Y., Yarrowia; Z., Zygosaccharomyces. 
Intrinsic (food properties)

Native: water activity, nutrient composition, $\mathrm{pH}$, endogenous enzyme activities, and antimicrobial components

Added or generated: organic acids, alcohols, $\mathrm{NaCl}$, and microbial primary and secondary metabolites

Extrinsic (environmental factors)

Storage temperature, atmospheric relative humidity, oxygen supply, and process operations (mixing, size reduction, mechanical separations, and heat treatments)

Natural mixed-culture fermentations usually have an element of homeostasis, which is supported by stimulatory and inhibitory effects amongst microorganisms. A few examples of such relatively stable mixed cultures in which yeasts and lactic acid bacteria interact are found in kefir (3), sourdoughs, pickles (4), and wine. In addition, molds and yeasts interact in the presence of bacteria in amylolytic starters (ragi), tempe, and soya sauce (2). Table 2 summarizes the major factors responsible for such stimulations and inhibitions.

\section{Fungal interactions of an inhibitory nature}

\section{Among molds}

In mold-fermented foods, a certain risk exists of contamination with mycotoxin-producing mold strains. Several investigations were made into the aflatoxin formation by Aspergillus flavus and Aspergillus parasiticus. In the presence of rapidly growing molds, e.g., Rhizopus microsporus var. oligosporus (in tempe) and Neurospora sitophila (in oncom), the latter appear to deplete available carbon sources (5), reducing aspergilli growth. Moreover, unidentified growth inhibiting factors were formed by $R$. microsporus var. oligosporus and $N$. sitophila (5). Volatile metabolites of Rhizopus oryzae (R. arrhizus), e.g., ethanol, isobutanol, and 3-methyl butanol were shown to double the lag time of $A$. flavus when they were present at $3-6 \%(\mathrm{v} / \mathrm{v})$ levels in the head space of stored bread (6). In the presence of other aspergilli, inhibition of growth, and (or) aflatoxin formation by Aspergillus niger (7) and $A$. oryzae (8) was observed. This was associated with accumulation of oxalic acid by $A$. niger (9) and gluconic acid by $A$. niger and Aspergillus tamarii (10). Aspergillus niger strains also produce antafumicins $\mathrm{A}$ and $\mathrm{B}(11)$, which are active against several phytopathogenic fungi of relevance to food quality, e.g., Botrytis cinerea and Fusarium oxysporum. While selecting Penicillium nalgiovense and Penicillium camembertii strains for use as commercial starters, it was observed that $29 \%$ of the tested strains significantly inhibited test strains of $A$. flavus, Penicillium commune, Penicillium verrucosum, and Cladosporium sp. (12).

\section{Among yeasts}

Especially during winemaking, interactions among yeasts are of importance for a timely attenuation and the development of the correct flavor and acidity of the wine. The ecology of the mixed flora in wine fermentation was reviewed earlier (2). During initial fermentation stages, wild yeasts (e.g., Hanseniaspora guilliermondii ${ }^{1}$ and Kloeckera apiculata) are

Yeast nomenclature is in accordance with Ref. 85. For the sake of recognition, some of the older names as used in the respective publications are mentioned in brackets in the text.
Table 2. Some factors involved in fungal interactions in food fermentations.

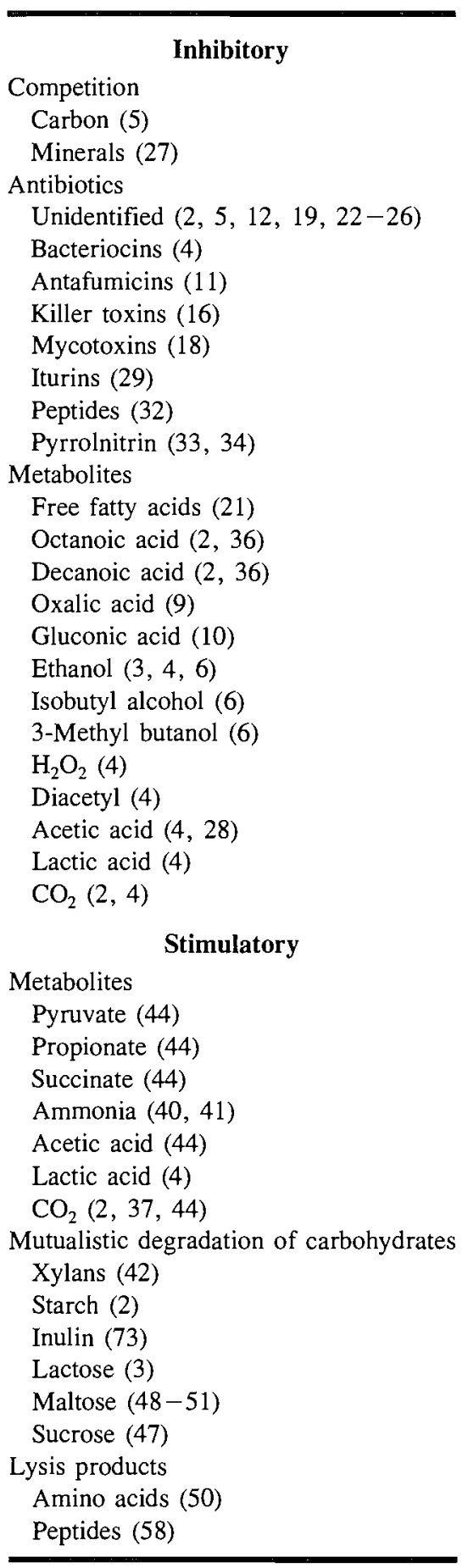

Note: Numbers in parentheses are references.

considered essential for later flavor development. Their production of esters, glycerol, and acetoin (13) is significant. Because of their limited ethanol tolerance, wild yeasts will be inhibited and Saccharomyces cerevisiae will dominate when more than $5 \%$ alcohol is present. In addition to more ethanol, the latter was reported to form considerable levels of $n$-propanol (13) in the presence of wild yeasts and, thus, characteristic flavors were generated. Other wild oxidative 
yeasts (e.g., Pichia membranaefaciens) can survive in low numbers throughout the fermentation (14). The latter are undesirable as they can lead to spoilage by film formation and acetic acid accumulation in the presence of oxygen.

Among the fermentative $S$. cerevisiae strains, the ecological importance of the killer factor and its possible causative role in sluggish or stuck fermentations (15) and in the dominance of winemaking strains is of much interest. Of the known killer types, K2 appears to be predominant in wineries. Experimental vinifications with mixed cultures of K (K2-killer) and $S$ (sensitive) $S$. cerevisiae revealed that inoculations at a $K: S$ mixing ratio of $1: 1$ or $1: 10$ resulted in rapid disappearance of most $S$ cells, with a rather normal fermentation completed by the $K$ strain. At lower $K$ levels $(K: S$ ratio $1: 100$ ) a majority of $S$ cells remained alive, but apparently these were not able to lyse and to release essential nitrogen for the fermentation to be completed (15). This mechanism was hypothesized to be a basis for stuck fermentations. From a practical point of view, addition of $\left(\mathrm{NH}_{4}\right)_{2} \mathrm{SO}_{4}$ remedied this nitrogen deficiency and enabled a $\mathrm{K}$-dominated completion of the fermentation. Alternatively, addition of adsorbent material (e.g., active charcoal, bentonite, or yeast cell walls) will inactivate killer toxin and allow S-completed fermentations.

Considering the effect of killer toxins on $S$ strains it is surprising that $\mathrm{K}$ strains are not the dominating population in spontaneously fermented wines. Interestingly however, chromosome DNA pulsed field gel electrophoresis of 26 killerresistant $\mathrm{N}$ (neutral) wine strains of $S$. cerevisiae revealed that $92 \%$ were derivatives of $\mathrm{K} 2$ killer toxin producing strains that had lost the ability to produce active toxin (16). Similar results were obtained in a Bordeaux winery (17) where it was observed that one karyotype of $S$. cerevisiae was stable and dominant in different wine vessels over a 2-year period. Again, almost all isolated strains were $\mathrm{N}$. One could hypothesize that a minority of $\mathrm{K}$ cells gradually degenerates (e.g., by point mutations or deletions in the $M$ double stranded RNA (16)) into an $\mathrm{N}$ population which may be protected from competing $S$ strains by the presence of killer toxin.

\section{Molds - yeasts}

Secondary metabolites include mycotoxins. For example, T-2 toxin produced by Fusarium spp. inhibited growth and ethanol production by $S$. cerevisiae at levels from $20 \mathrm{ppm}$. It was postulated that $\mathrm{T}-2$ toxin affects the energy metabolism of mitochondria (18).

\footnotetext{
Molds - bacteria

Rhizopus microsporus var. oligosporus, the major functional organism in tempe fermentation, was found to produce an antibiotic 5.5-kDa protein (19) with a broad $\mathrm{pH}$ range of activity and considerable thermal stability. Although it was active at $<1$ ppm against Bacillus spp., reported growth curves suggest that the antibiotic causes a delay of growth rather than death. This might explain why growth of bacilli in tempe may still achieve significant levels (20). In Roquefort blue-veined cheese, the presence of Escherichia coli and Staphylococcus aureus is undesirable from a hygienic and public safety point of view. It was observed that in addition to intrinsic inhibitory effects $(\mathrm{pH}, \mathrm{NaCl}$, competing lactic acid bacteria) in the cheese environment, the functional mold Penicillium roqueforti contributes to the inhibition of bac-
}

teria (21). The strongest antibacterial effect was manifested by strains having high proteolytic and lipolytic activities, and an indirect inhibition through the formation of free fatty acids was supposed.

Lactic acid bacteria are of great importance in fermented foods. Their antimicrobial effect is ascribed to competition, production of organic acids and other metabolites of low molecular mass, as well as proteinaceous bacteriocins (4). Several dairy starters, e.g., Lactococcus lactis ssp. lactis biovar. diacetylactis and Lactobacillus acidophilus reportedly $(22-25)$, have antifungal activity against $A$. fumigatus, $R$. stolonifer and to a lesser extent against $A$. parasiticus and Rhizopus spp. The nature of these inhibitions remains to be investigated. Likewise, Lactobacillus plantarum and Pediococcus pentosaceus were found to inhibit Fusarium contamination during barley malting for brewery purposes (26). The same species of lactic acid bacteria also inhibited aflatoxin production by $A$. parasiticus in fermented meat (27). Supposedly, the latter effect included $(i$ ) failure of $A$. parasiticus in establishing effective competition for the nutrients necessary for aflatoxin production at the prevailing low temperature $\left(15^{\circ} \mathrm{C}\right)$, and (ii) $\mathrm{Mn}$ deficiency caused by accumulation in lactic acid bacteria. Heterofermentative acetic acid production by lactic acid bacteria during soaking of soya beans was found to delay the germination of sporangiospores of $R$. microsporus var. oligosporus, the functional mold for tempe production (28).

Bacillus spp. are known to produce several antimicrobial substances. Bacillus subtilis is able to produce a group of broad-spectrum iturins including bacillomycin, mycosubtilin, and the peptidolipid iturin-A (29). The latter compound inhibits the growth of, for example, Penicillium italicum, Penicillium viridicatum, Aspergillus ochraceus, Aspergillus versicolor, and could be used in biorational control (i.e., using the inhibitory compound rather than the living bacterium) in foods. However, insufficient data are presently available about its safety and in vivo effectivity (29). Apparently, iturin-A does not consistently inhibit growth or aflatoxin production of $A$. flavus and $A$. parasiticus $(30,31)$. Bacillus licheniformis was observed to produce an antifungal $0.77-\mathrm{kDa}$ peptide whereas Bacillus pumilus can be effectively used as a biological control agent against Penicillium digitatum on oranges when applied as a $10^{10}-10^{12}$ colony forming units (cfu)/mL suspension (32). In the area of biological control for shelflife extension, Enterobacter cloacae inhibits Rhizopus rot in peaches and Pseudomonas spp. inhibit Penicillium expansum on apples (32), whereas Pseudomonas cepacia produces the antifungal pyrrolnitrin, which is of interest in seed protection against, for example Trichoderma viride (33) and Fusarium sambucinum (34)

\section{Yeasts - bacteria}

Whereas Pediococcus halophilus is classified as a homofermentative lactic acid bacterium, it nevertheless forms $0.2-0.3 \%$ acetic acid from citric acid during the maturation of soya sauce. At the prevailing $\mathrm{pH}(4.6-4.8)$ this combination is inhibitory to Zygosaccharomyces rouxii (35). Conversely, bacteria can be inhibited by yeasts. For example, the malolactic fermenting Leuconostoc oenos are inhibited in wine by the fatty acids (e.g., undissociated decanoic acid) produced by $S$. cerevisiae (36). 


\section{Fungal interactions of a stimulatory nature}

Among molds

In the area of mushroom cultivation, it is well known that the growth of the edible mushroom Agaricus bisporus is enhanced by thermophilic fungi, notably Scytalidium thermophilum, in compost. Recently it was pointed out that this stimulation was mainly due to $\mathrm{CO}_{2}$ formed by Scytalidium thermophilum (37). At levels of approximately $0.5 \% \mathrm{CO}_{2}$ the effect was strongest.

\section{Molds - yeasts}

In food fermentations of protein-rich raw materials usually some extent of proteolysis takes place. Mold-fermented foods, e.g., soya bean tempe ( $R$. microsporus var. oligosporus) (20) and cheeses ( $P$. roqueforti, $P$. camembertii) $(38,39)$, as well as some bacterial fermentations, e.g., soya bean kinema (Bacillus spp.) (40), have in common that up to approximately $0.2 \% \mathrm{w} / \mathrm{w}$ of ammonia is formed as a result of proteolytic activity. As a result, the $\mathrm{pH}$ of such products tends to increase by one to two $\mathrm{pH}$ units. It was found that in groundnuts and maize, fermentative production of ammonia could help to degrade the majority of aflatoxin B1 contamination (M.J.R. Nout, unpublished data). Another positive aspect of ammonia formation is that it is a convenient source of assimilable nitrogen for microorganisms with low proteolytic activity, e.g., yeasts $(39,41)$. On the other hand, excessive ammonia accumulation causes unacceptable off flavors (20).

\section{Molds - bacteria}

At a very large scale, animal feed is fermented by ruminants. The rumen microflora is a strictly anaerobic complex mixture including fungi and bacteria, which can deal quite efficiently with raw polysaccharides of vegetable origin. The finding that the rumen mold Neocallimastix frontalis achieves higher xylan utilization rate in the presence of the nonxylanolytic rumen bacteria Bacteroides ruminicola, Succinivibrio dextrinosolvens, and Selenomonas ruminantium confirms that mutualism is of importance in the rumen (42).

\section{Yeasts-bacteria}

Stable mixed cultures of yeasts and lactic acid bacteria are found in products generated and maintained using an enrichment process (e.g., kefir grains and cereal sourdoughs). Milk kefir is a refreshing dairy beverage that has undergone a mixed lactic acid - alcoholic fermentation by a mutualistic combination of yeasts and lactic acid bacteria embedded in a resilient polysaccharide (kefiran) matrix, forming grains that are used as a source of immobilized inoculum. In Spanish kefir grains the predominant yeasts (Torulaspora delbrueckii and $S$. cerevisiae) were unable to assimilate lactose and thus depended on other lactose assimilating microorganisms (lactic acid bacteria and a minority of $\mathrm{Lac}^{+}$yeasts) for their supply of carbon source. The lactic acid bacteria (mainly heterofermentative lactobacilli, i.e., Lactobacillus brevis, Lactobacillus viridescens, Lactobacillus kefir, and Lactobacillus fermentum) produced lactic acid that could serve partly as a source of carbon. Their antimicrobial metabolites supposedly protected the mixed culture against contaminating microorganisms (3).

Sugary kefir $(43,44)$ and tibicos $(45)$ are similar mutual- istic combinations of yeasts and lactic acid bacteria, embedded in polysaccharide (including dextran). They have some resemblance to "Mother of Vinegar' and tea fungus (Kombucha) (46), although the latter have a higher content of acetic acid bacteria. In contrast to milk kefir, sugary kefir and tibicos are used as an immobilized inoculum to ferment sugar solutions (i.e., molasses, sugary tea, etc.), to produce a fizzy beverage with a low (2\%) alcohol and acetic acid $(0.05 \%)$ and a rather high ( $1 \%$ ) lactic acid content. In Mexican tibicos (45), Candida valida and Candida famata were found in stable combination with lactic and acetic acid bacteria. From sugary kefir, several yeasts (Zygosaccharomyces [S.] florentinus, Torulaspora [S.] pretoriensis, S. cerevisiae, Candida lambica, C. valida, $K$. apiculata) and lactic acid bacteria (Lactobacillus hilgardii, Lactobacillus paracasei ssp. paracasei, Leuconostoc mesenteroides ssp. dextranicum) were isolated, and interactive properties of $L$. hilgardii, Z. [S.] florentinus, and C. lambica were investigated (43). Stimulation of the lactobacilli by the culture supernatant of the yeasts was observed and was ascribed to $\mathrm{CO}_{2}$ production. Subsequently, it was established that $Z$. [S.] florentinus stimulated $L$. hilgardii by several of its metabolites, i.e., $\mathrm{CO}_{2}$, pyruvate, propionate, acetate, and succinate (44). Interestingly, no stimulatory effect on $L$. hilgardii could be detected by adding vitamins or nitrogen compounds. Conversely, $L$. hilgardii had an inhibitory effect on growth and ethanol production by Z. [S.] florentinus. Likewise, it was found that the growth of lactic acid bacteria (Lactobacillus casei ssp. pseudoplantarum) was stimulated during alcoholic fermentation of molasses with $S$. cerevisiae operating on a cell-recycle principle. This was explained (47) by the invertase activity caused by the high cell density of $S$. cerevisiae releasing significant levels of glucose and fructose from sucrose. At the same time, no evidence for the involvement of nitrogenous compounds was observed.

Cereal sourdoughs could be described as enrichment cultures of relatively stable combinations of yeasts and (mainly) heterofermentative lactic acid bacteria. Sourdoughs based on rye, wheat, sorghum, or other cereal flours are used as a leavening agent in the production of bread. Depending on the type and composition of the flour, dough-making conditions, and incubation environment, rather characteristic mutualistic combinations develop during the long periods (months or years) that sourdoughs are maintained. Typical lactic acid bacteria encountered include Lactobacillus sanfrancisco (presently including $L$. brevis ssp. lindneri), Lactobacillus fructivorans, L. fermentum, L. plantarum, and Lactobacillus reuteri. Frequently occurring yeasts are $S$. cerevisiae, Pichia saitoi, Candida krusei, Candida holmii, Candida milleri, and Saccharomyces exiguus. The likely mechanism of the stability of sourdoughs has been discussed (48), and recent findings (49-51) may serve to update the understanding of this selfprotecting and self-regulating system. Wild strains of sourdough lactobacilli are specialized towards assimilation of maltose, the major source of assimilable carbon in cereal dough. There is a regular supply of maltose, generated by the endogenous cereal amylases. In principle, sugar transport in lactic acid bacteria can occur via $(i)$ high-affinity ATP-dependent transport or high-affinity phosphoenolpyruvate:sugar phosphotransferase systems and (ii) low-affinity secondary transport systems driven by (electro)chemical gradients that are effective at relatively high sugar concentra- 
tions. In maltose-grown $L$. sanfrancisco maltose uptake is via maltose $-\mathrm{H}^{+}$symport. Within the cell, maltose is phosphorylated and split into glucose-1-phosphate and free glucose. About $50 \%$ of the latter leaves the cell through a glucose uniport (52). At lower pH the proton-motive force will be increased and so will be the maltose uptake. When all maltose has been taken up, the exported glucose will be assimilated in pure cultures. However, in sourdough the released glucose will be assimilated by yeasts. It was found in sourdough that glucose is exported at the same rate as maltose is imported (49) reaching glucose levels up to $13 \mathrm{mM}$. In the presence of sufficient maltose, maltosephosphorylase, produced by lactobacilli, is not glucose-repressed. This factor is considered essential for the domination of the lactobacilli over microorganisms competing for the same carbon source (i.e., maltose). As most other maltose-assimilating organisms are glucose repressed, the export of glucose would thus serve as an indirect and temporary inhibitor (49). Nevertheless, it was shown that maltose-assimilating $S$. cerevisiae compete with $L$. brevis ssp. lindneri resulting in reduced bacterial growth and organic acid production (53). It was also suggested (48) that lactic acid bacteria may produce antibiotics and, thus, support the stability of the sourdough population. At present, no direct evidence has been presented to confirm or contradict this hypothesis. On the other hand, most yeasts present in sourdough are quite robust (54). They tolerate acetic acid, but they do not compete with the lactic acid bacteria because they cannot assimilate maltose, only glucose and fructose. The role of yeasts as suppliers of growth factors was suggested (48). Indeed, it was found (50) that $S$. cerevisiae and $S$. exiguus excrete alanine, glutamic acid, leucine, and valine during the stationary phase of growth and that these amino acids stimulated $L$. brevis ssp. lindneri. It was shown earlier that lactic acid bacteria from sourdoughs required vitamins (55) and varying numbers of amino acids (56), which could be supplied either by fresh yeast extractives (57), a peptide (58), or live yeast cells (59). Also, it was observed that in wheat doughs, proline and arginine are assimilated faster by mixed yeast - lactic acid bacteria cultures than by the individual microbial components (51). However, the latter study also showed that considerable levels of free amino acids are generated in dough by proteolytic enzymes of the cereal grain and that yeasts ( $S$. cerevisiae) consume, rather than release amino acids (51). It appears that the extent of acidification of lactic fermentations of cereal doughs will, inter alia, depend on the availability of micronutrients for lactic acid bacteria. If the latter are deficient in the raw material to be fermented, they will have to be supplied by yeast cells and, consequently, an equilibrium situation will be established with final $\mathrm{pH}$ values and acetic acid concentrations enabling adequate yeast growth (60). It still remains to be clarified to what extent yeasts play a role as growth stimulators for sourdough lactic acid bacteria.

\section{Developments in cocultivation technology}

In the preceding sections, several mechanisms were discussed whereby components of mixed cultures affect each others growth and metabolic activity. The following section deals with some mixed-culture systems with components that do not show a microbial interaction as such but which have complementary metabolic activity. For such cocultures to be successful, the organisms must be compatible, and the medium composition and incubation conditions must be an acceptable compromise for both.

\section{Mixed molds}

In the area of mold-fermented foods, several pure culture inocula are available commercially. Penicillium roqueforti, $P$. camembertii, and $P$. nalgiovense are widely marketed as cheese- and meat-fermentation starters. On sausage casings, mixed inocula of Scopulariopsis candida and $P$. nalgiovense showed improved attachment to casings (61) because Scopulariopsis candida could penetrate them and $P$. nalgiovense attached into the Scopulariopsis candida mycelium. Also, simultaneous growth of $P$. roqueforti and $P$. camembertii is possible, as exemplified in the German cheese Bayerisch Blau (62), where $P$. roqueforti grows inside and $P$. camembertii grows on the surface of the cheese. Considering the potential mycotoxin forming properties of penicillia it would be prudent to investigate whether any stress reactions occur in such mixed cultures that could trigger mycotoxin formation. In the area of tropical mold-fermented foods it is well known that koji's for soya sauce and saké contain well-balanced mixtures of aspergilli, i.e., A. oryzae and Aspergillus sojae. The fact that such mixed cultures produce more enzymes while consuming less starch compared with single pure cultures has been associated with possible hyphal incompatibity (63). Nevertheless these individual components do not appear to either depend on or to competively exclude one another. Also, the traditional tempe inoculum (usar) contains Rhizopus strains (64), which grow as a mixed culture during the tempe fungal fermentation stage.

\section{Mixed yeasts}

The major objective of mixed yeast cocultivations is to convert carbohydrate sources directly into ethanol or microbial protein at maximum yield. As high-yielding and ethanoltolerant Saccharomyces spp. are poor degraders of starch or pentoses, cocultures are carried out with yeasts able to degrade such substrates. During selection of compatible pairs of alcohol-producing Saccharomyces spp. and xylose fermenting yeasts for production of alcohol from lignocellulosic waste, it was observed that none of the Saccharomyces inhibited the xylose fermenters but a number of the latter inhibited Saccharomyces, some by killer factors (65). Using a combination of Pichia stipitis and a respiratory-deficient $S$. cerevisiae [diastaticus], mixtures of $30 \%$ xylose and $70 \%$ glucose were fermented to ethanol in a continuous culture (66). The performance of Pichia stipitis was a limiting factor, requiring a respiratory-deficient $S$. cerevisiae [diastaticus] mutant to to create a favourable $\mathrm{O}_{2}$ profile. In addition, glucose levels had to be limited to avoid repression of the xylose assimilation. Similarly, direct conversion of soluble starch to ethanol, using a coculture of Endomyces fibuliger and $S$. cerevisiae was reported (67). Endomyces fibuliger is able to degrade starch by amylase and amyloglucosidase. In the absence of yeast extract, it was unable to assimilate the released glucose. Glucose repression of the starch degradation is avoided by its simultaneous conversion to ethanol by $S$. cerevisiae. Another combination of a starch-degrading amylase-derepressed mutant of Schwanniomyces occidentalis, with ethanol producing $S$. cerevisiae was used to convert grain sorghum directly 
into ethanol and single cell protein (68). The derepressed Schwanniomyces occidentalis degraded the starch completely, but because of its low ethanol tolerance, $S$. cerevisiae was required to obtain significant ethanol yields. Per $1000 \mathrm{~kg}$ of sorghum, $390 \mathrm{~L}$ of ethanol and $185 \mathrm{~kg}$ crude protein were obtained (68). In combination with C. utilis and the derepressed Schwanniomyces occidentalis, protein-enriched sorghum could be obtained by conversion of $\left(\mathrm{NH}_{4}\right)_{2} \mathrm{SO}_{4}$ and starch (69). Considering the world market prices of competing vegetable proteins, it is doubtful, however, whether protein enrichment by fermentation is economically feasible.

Mixed molds and yeasts

Several molds are superior producers of carbohydrases, especially in view of the degradation of cellulose and hemicelluloses. The cellulase - hemicellulase activity of Sclerotium rolfsii was used to degrade alkali-treated rice straw. By simultaneous glucose transformation to ethanol using either $S$. cerevisiae or Candida tropicalis the glucose repression of the enzyme system could be avoided (70). In a similar way, $F$. oxysporum was incubated with $S$. cerevisiae inoculum on sorghum, resulting in ethanol yield of $68 \%$ of the theoretical value (71). Higher ethanol yields ( $83-84 \%$ of theory) were obtained in 3 days from chicory and dahlia inulin by saccharification with inulinase produced by $A$. niger and simultaneous ethanol fermentation using an ethanol tolerant $S$. cerevisiae (72).

\begin{abstract}
Mixed molds and bacteria
The importance of no-cook processes for direct conversion of starch into ethanol were discussed earlier (2). Significant savings can be made on energy and sophisticated equipment if thermal gelatinization and liquefaction of starch and media sterilization are omitted. Such processes require a microbial system that efficiently degrades native starch. Cocultures for that purpose have been described (73). Another requirement is adequate control of contaminants, especially if continuous systems are employed. Interestingly, it was found that Aspergillus awamori, $R$. oryzae [japonicus], and Zymomonas mobilis coimmobilized in alginate for direct conversion of native rice starch into ethanol, performed well in the presence of $0.1 \%$ neupectin- $\mathrm{L}$, an oligogalacturonic acid with a degree of polymerization of 10 having antimicrobial activity against contaminating bacteria (73).
\end{abstract}

\begin{abstract}
Mixed yeasts and bacteria
An elegant coculture system composed of the nitrogen fixing Acetobacter diazotrophicus and the starch degrading Lipomyces kononenkoae was described (74). In a basal mineral and vitamin medium without added nitrogen source, starch degradation by $L$. kononenkoae was enabled by nitrogen supply through Acetobacter diazotrophicus, the latter depending on assimilable carbon supplied by the yeast. It was estimated that approximately $40 \%$ of the fixed $\mathrm{N}_{2}$ was released to the yeast, being considerably higher than the nitrogen release by other $\mathrm{N}_{2}$-fixing organisms (e.g., Azospirillum spp.).
\end{abstract}

\section{Impact of modern biotechnology}

As an alternative of natural mixed cultures or compatible cocultures to ferment food-grade materials, the tools are now at hand to combine the key functions of the mixed flora into single strains of starter cultures. Several reviews deal with the molecular-genetic aspects of foreign gene expression (75) and the application of recombinant DNA fungi in food manufacture (76). It would fall outside the scope of this paper to give a full account of all recombinant DNA constructs of interest in the food industry, but a few areas will be mentioned which appear relevant to the current issue of substitution of mixed cultures or cocultures.

The first example is the direct conversion of polysaccharides into ethanol. Limited ability to digest starch by $S$. cerevisiae can be overcome using recombined DNA constructs expressing Schwanniomyces occidentalis amylase and glucoamylase or $A$. oryzae $\alpha$-amylase (76), and maltodextrins can be fermented by $S$. cerevisiae expressing $C$. tropicalis $\alpha$-glucosidase (76) or by $S$. cerevisiae glucose derepressed mutants (77). Similarly, the glucose production of $A$. oryzae for saké brewing could be improved by increasing its ratio of glucoamylase/ $\alpha$-amylase activity from 0.37 to 1.01 by expression of $A$ spergillus shirousamii glucoamylase (78). Inulin can be fermented directly into ethanol by a $S$. cerevisiae expressing Kluyveromyces marxianus inulinase, xylose by a $S$. cerevisiae expressing $B$. pumilus endo- $1,4-\beta$-xylanase and $\beta$-glucosidase or Pichia stipitis xylose reductase and xylitol dehydrogenase, and lactose by a $S$. cerevisiae expressing $A$. niger or Kluyveromyces lactis $\beta$-galactosidase (76). Compared with parent strains, the performance of some of these constructs is definitely superior giving earlier brewing attenuation (77) and higher alcohol yield (78) with similar or improved organoleptic characteristics (78). At present, no published data are available enabling a comparison of the performances of recombinant DNA constructs with those of equivalent cocultures.

Another area of relevance is winemaking that experiences an increasing popularity of dry yeast inoculants. Using an elegant mitochondrial DNA restriction analysis, the fate of wine $S$. cerevisiae dry inoculant during vinification at the winery level was evaluated and compared with the activity of wild yeast strains present in the must (79). Although the inoculated strain was responsible for the fermentation, the first stages of the fermentation were dominated by wild $S$. cerevisiae strains, some of which persisted throughout the process. Several recombinant DNA $S$. cerevisiae wine yeast constructs have been prepared, e.g., expressing $\mathrm{K} 1$ and $\mathrm{K} 3$ killer toxins for dominance (80) or Trichoderma longibrachiatum $\beta$-1,4-endoglucanase for increased frutal aroma (81). Other glycosidases (e.g., $\beta$-glucosidase, $\alpha$-arabinosidase, and $\alpha$-rhamnosidase) are also effective flavor enhancers by releasing volatile grape terpenols (e.g., linalol and geraniol) from their nonvolatile glycosides (82). Hybrids of cryophilic Saccharomyces bayanus and mesophilic $S$. cerevisiae wine strains were stable, had promising fermentation characteristics at $10^{\circ} \mathrm{C}$, and released more flavor substances than parent strains (83). Presently, very little data are available to evaluate the effectiveness of these new strains. In this respect it should be taken into account that genetic modification could also lead to inferior characteristics as was found with California and Pasteur champagne parent strains, when compared with their inbred homothallic and hybrid heterothallic derivatives (84).

\section{Conclusion}

In conclusion, fungal interactions observed in natural mixedculture fermentations may be efficiently exploited at a cocultivation level or by recombinant DNA constructs com- 
bining relevant metabolic abilities. More data is becoming available to demonstrate that conversion yields of polymeric substrates can be significantly increased with these approaches. A challenge for the future is to focus ecological and biotechnological experience on the improvement of safety and organoleptic quality of foods.

\section{References}

1. Campbell-Platt, G., and Cook, P.E. 1989. Fungi in the production of foods and food ingredients. J. Appl. Bacteriol. 67(Suppl.): 117S-131S.

2. Nout, M.J.R. 1992. Ecological aspects of mixed-culture food fermentations. In The fungal community: its organization and role in the ecosystem. Edited by G.C. Carroll and D.T. Wicklow. 2nd ed. Marcel Dekker, New York. pp. 817-851.

3. Angulo, L., Lopez, E., and Lema, C. 1993. Microflora present in kefir grains of the Galician region (North-West of Spain). J. Dairy Res. 60: 263-267.

4. Nout, M.J.R., and Rombouts, F.M. 1992. Fermentative preservation of plant foods. J. Appl. Bacteriol. 73(Suppl.): $136 \mathrm{~S}-147 \mathrm{~S}$.

5. Nout, M.J.R. 1989. Effect of Rhizopus and Neurospora spp. on growth of Aspergillus flavus and A. parasiticus and accumulation of aflatoxin B1 in groundnut. Mycol. Res. 93: $518-523$.

6. Lanciotti, R., and Guerzoni, M.E. 1993. Competitive inhibition of Aspergillus flavus by volatile metabolites of Rhizopus arrhizus. Food Microbiol. 10: 367-377.

7. Paster, N., Pushinsky, A., Menasherov, M., and Chet, H. 1992. Inhibitory effect of Aspergillus niger on the growth of Aspergillus ochraceus and Aspergillus flavus, and on aflatoxin formation. J. Sci. Food Agric. 58: 589-591.

8. Sardjono, Rahayu, K., and Sudarmadji, S. 1992. Growth and aflatoxin production by Aspergillus flavus in mixed culture with Aspergillus oryzae. ASEAN Food J. 7: 30-33.

9. Shanta, T., and Rati, E.R. 1990. Isolation and characterization of an aflatoxin-inhibiting metabolite from A. niger. Curr. Sci. (Bangalore), 59: 326-327.

10. Shanta, T., Rati, E.R., and Bhavani Shankar, T.N. 1990. Behaviour of Aspergillus flavus in presence of Aspergillus niger during biosynthesis of aflatoxin $\mathrm{B} 1$. Antonie Leeuwenhoek, 58: 121-127.

11. Fujimoto, Y., Miyagawa, H., Tsurushima, T., Irie, H., Okamura, K., and Ueno, T. 1993. Structures of antafumicins $\mathrm{A}$ and $\mathrm{B}$, novel antifungal substances produced by the fungus Aspergillus niger $\mathrm{NH}-401$. Biosci., Biotechnol., Biochem. 57: 1222-1224.

12. Andersen, S.J. 1993. Colony interactions between moulds belonging to species used as starter cultures for fermentation of sausages and potential contaminants. In Sixth European Congress on Biotechnology, June 13-17, Firenze, Italy, European Federation of Biotechnology. Finito di Stampare dalla Tipografia TAF s.r.l., Firenze, Italy. Abstract Books Vol. 1. Abstr. MO148.

13. Zironi, R., Romano, P., Suzzi, G., Battistutta, F., and Comi, G. 1993. Volatile metabolites produced in wine by mixed and sequential cultures of Hanseniaspora guilliermondii or Kloeckera apiculata and Saccharomyces cerevisiae. Biotechnol. Lett. 15: 235-238.

14. Mora, J., and Rossello, C. 1992. The growth and survival of Pichia membranaefaciens during fermentation of grape juice. Am. J. Enol. Vitic. 43: 329-332.

15. Carrau, F.M., Neirotti, E., and Gioia, O. 1993. Stuck wine fermentations-effect of killer sensitive yeast interactions. J. Ferment. Bioeng. 76: 67-69.

16. Cansado, J., Velazquez, J.B., Calo, P., Sieiro, C., Longo, E., and Villa, T.G. 1992. Characterization of killer-resistant strains of Saccharomyces cerevisiae isolated from spontaneous fermentations. FEMS Microbiol. Lett. 97: $13-17$.

17. Frezier, V., and Dubourdieu, D. 1992. Ecology of yeast strain Saccharomyces cerevisiae during spontaneous fermentation in a Bordeaux winery. Am. J. Enol. Vitic. 43: $375-380$.

18. Koshinsky, H.A., Cosby, R.H., and Khachatourians, G.G. 1992. Effects of T-2 toxin on ethanol production by Saccharomyces cerevisiae. Biotechnol. Appl. Biochem. 16: $275-286$

19. Kobayasi, S.Y., Okazaki, N., and Koseki, T. 1992. Purification and characterization of an antibiotic substance produced from Rhizopus oligosporus IFO 8631. Biosci. Biotechnol. Biochem. 56: 94-98.

20. Nout, M.J.R., and Rombouts, F.M. 1990. Recent developments in tempe research. J. Appl. Bacteriol. 69: $609-633$.

21. Laporte, E., Guiraud, J.P., and Reverbel, J.P. 1992. Antimicrobial action associated to Roquefort cheese technology-influence of the Penicillium roqueforti strain. Sci. Aliments, 12: 729-741.

22. Batish, V.K., Grover, S., and Lal, R. 1989. Screening lactic starter cultures for antifungal activity. Cult. Dairy Prod. J. 24: 21, 23-25.

23. Batish, V.K., Lal, R., and Chander, H. 1990. Effect of nutritional factors on the production of antifungal substance by Lactococcus lactis subsp. lactis biovar. diacetylactis. Aust. J. Dairy Technol. 45: 74-76.

24. Batish, V.K., Lal, R., and Grover, S. 1990. Studies on environmental and nutritional factors on production of antifungal substance by Lactobacillus acidophilus R. Food Microbiol. 7: 199-206.

25. Batish, V.K., Lal, R., and Grover, S. 1991. Interaction of $S$. lactis subsp. diacetylactis DRC-1 with Aspergillus parasiticus and $A$. fumigatus in milk. Cult. Dairy Prod. J. 26: $13-14$.

26. Haikara, A., and Niku-Paavola, M.-L. 1993. Fungicidic substances produced by lactic acid bacteria. FEMS Microbiol. Rev. 12(1-3): P120. (Abstr.)

27. Luchese, R.H., Martins, J.F.P., and Harrigan, W.F. 1992. Aflatoxin production in a meat mix model system in the presence of Pediococcus and Lactobacillus. J. Food Prot. 55: $583-587$.

28. De Reu, J.C., Rombouts, F.M., and Nout, M.J.R. 1995. Influence of acidity and initial substrate temperature on germination of Rhizopus oligosporus sporangiospores in tempe fermentation. J. Appl. Bacteriol. 78: 200-208.

29. Klich, M.A., Lax, A.R., and Bland, J.M. 1991. Inhibition of some mycotoxigenic fungi by iturin-A, a peptidolipid produced by Bacillus subtilis. Mycopathologia, 116: 77-80.

30. Kimura, N., and Hirano, S. 1988. Inhibitory strains of Bacillus subtilis for growth and aflatoxin-production of aflatoxigenic fungi. Agric. Biol. Chem. 52: 1173-1179.

31. Klich, M.A., Lax, A.R., Bland, J.M., and Scharfenstein, L.L. 1993. Influence of iturin-A on mycelial weight and aflatoxin production by Aspergillus flavus and Aspergillus parasiticus in shake culture. Mycopathologia, 123: $35-38$.

32. Huang, Y., Wild, B.L., and Morris, S.C. 1992. Postharvest biological control of Penicillium digitatum decay on citrus fruit by Bacillus pumilus. Ann. Appl. Biol. 120: $367-372$.

33. Upadhyay, R.S., Visintin, L., and Jayaswal, R.K. 1991. 
Environmental factors affecting the antagonism of Pseudomonas cepacia against Trichoderma viride. Can. J. Microbiol. 37: 880-884.

35. Yamamoto, Y., Imaizumi, H., Higashi, K., and Yoshii, H. 1992. Studies on the manufacture of shiro-shoyu. II. Inhibitory effects of Pediococcus halophilus on growth of Zygosaccharomyces rouxii in shiro-shoyu fermentation. Nippon Shokuhin Kogyo Gakkaishi, 39: 934-938.

36. Avedovech, R.M., Jr., McDaniel, M.R., Watson, B.T., and Sandine, W.E. 1992. An evaluation of combinations of wine yeast and Leuconostoc oenos strains in malolactic fermentation of Chardonnay wine. Am. J. Enol. Vitic. 43: $253-260$.

37. Wiegant, W.M., Wery, J., Buitenhuis, E.T., and Debont, J.A.M. 1992. Growth-promoting effect of thermophilic fungi on the mycelium of the edible mushroom Agaricus bisporus. Appl. Environ. Microbiol. 58: 2654-2659.

38. Philipp, S., and Pedersen, P.D. 1988. Mould cultures for the food industry. A short review with special reference to the cheese- and sausage production. Dan. Dairy Food Ind. Worldwide, 6: 8, 10-12.

39. Besancon, X., Smet, C., Chabalier, C., Rivemale, M., Reverbel, J.P., Ratomahenina, R., and Galzy, P. 1992. Study of surface yeast flora of Roquefort cheese. Int. J. Food Microbiol. 17: 9-18.

40. Sarkar, P.K., Cook, P.E., and Owens, J.D. 1993. Bacillus fermentation of soybeans. World J. Microbiol. Biotechnol. 9: 295-299.

41. Lacerda, V., Marsden, A., and Ledingham, W.M. 1992. Ammonia assimilation in Saccharomyces cerevisiae under chemostatic growth. Appl. Biochem. Biotechnol. 32: 15-21.

42. Williams, A.G., Withers, S.E., and Joblin, K.N. 1991. Xylanolysis by cocultures of the rumen fungus Neocallimastix frontalis and ruminal bacteria. Lett. Appl. Microbiol. 12: 232-235.

43. Leroi, F., and Pidoux, M. 1993. Detection of interactions between yeasts and lactic acid bacteria isolated from sugary kefir grains. J. Appl. Bacteriol. 74: 48-53.

44. Leroi, F., and Pidoux, M. 1993. Characterization of interactions between Lactobacillus hilgardii and Saccharomyces florentinus isolated from sugary kefir grains. J. Appl. Bacteriol. 74: 54-60.

45. Armijo, C., Taboada, J., Lappe, P., and Ulloa, M. 1991. Products of fermentation by tibicos and associated yeasts. Rev. Latinoam. Microbiol. 33: 17-23.

46. Reiss, J. 1987. The 'tea fungus' and its metabolic products. Dtsch. Lebensm. Rundsch. 83: 286-290.

47. Essia Ngang, J.J., Wolniewicz, E., Letourneau, F., and Villa, P. 1992. Stimulation of lactobacilli during alcoholic fermentation: action of sucrose hydrolysis by yeast. Biotechnol. Lett. 14: 741-746.

48. Wood, B.J.B., and Hodge, M.M. 1985. Yeast - lactic acid bacteria interactions and their contribution to fermented foodstuffs. In Microbiology of fermented foods. Vol. 1. Edited by B.J.B. Wood. Elsevier Applied Science Publishers, Barking, U.K. pp. 263-293.

49. Stolz, P., Bocker, G., Vogel, R.F., and Hammes, W.P. 1993. Utilisation of maltose and glucose by lactobacilli isolated from sourdough. FEMS Microbiol. Lett. 109: 237-242.

50. Gobbetti, M., Corsetti, A., and Rossi, J. 1993. The sour dough microflora: study of the interactions between lactic acid bacteria and yeasts. FEMS Microbiol. Rev. 12(1-3): P173. (Abstr.)

51. Collar, C., Mascaros, A.F., and De Barber, C.B. 1992. Amino acid metabolism by yeasts and lactic acid bacteria during bread dough fermentation. J. Food Sci. 57: $1423-1427$.

52. Neubauer, H., Glaasker, E., Hammes, W.P., Poolman, B., and Konings, W.N. 1994. Mechanism of maltose uptake and glucose excretion in Lactobacillus sanfrancisco. J. Bacteriol. 176(10): 3007-3012.

53. Gobbetti, M., Corsetti, A., and Rossi, J. 1994. The sourdough microflora. Interactions between lactic acid bacteria and yeasts: metabolism of carbohydrates. Appl. Microbiol. Biotechnol. 41: 456-460.

54. Spicher, G., and Schröder, R. 1980. Die Mikroflora des Sauerteiges. VIII. Die Faktoren des Wachstums der im "Reinzuchtsauer" auftretenden Hefen. Z. Lebensm. Unters. Forsch. 170: 119-123.

55. Spicher, G., and Schröder, R. 1979. Die Mikroflora des Sauerteiges. V. Das Vitaminbedürfnis der in "Reinzuchtsauern" und in Sauerteigen anzutreffenden stäbchenförmigen Milchsäurebakterien (Genus Lactobacillus Beijerinck). Z. Lebensm. Unters. Forsch. 168: 188- 192.

56. Spicher, G., and Schröder, R. 1979. Die Mikroflora des Sauerteiges. VI. Das Aminosäurebedürfnis der in "Reinzuchtsauern" und in Sauerteigen anzutreffenden stäbchenförmigen Milchsäurebakterien (Genus Lactobacillus Beijerinck). Z. Lebensm. Unters. Forsch. 168: 397-401.

57. Kline, L, and Sugihara, T.F. 1971. Microorganisms of the San Francisco sourdough bread process. II. Isolation and characterization of undescribed bacterial species responsible for souring activity. Appl. Microbiol. 21: 459-465.

58. Sugihara, T.F. 1985. Microbiology of breadmaking. In Microbiology of fermented foods. Vol. 1. Edited by B.J.B. Wood. Elsevier Applied Science Publishers, Barking, U.K. pp. 249-261.

59. Spicher, G., Rabe, E., Sommer, R., and Stephan, H. 1981. Die Mikroflora des Sauerteiges. XIV. Über das Verhalten homofermentativer Sauerteigbakterien und Hefen bei gemeinsamer Kultur. Z. Lebensm. Unters. Forsch. 173: $291-296$.

60. Nout, M.J.R. 1991. Ecology of accelerated natural lactic fermentation of sorghum-based infant food formulas. Int. J. Food Microbiol. 12: 217-224.

61. Hwang, H.-J., Vogel, R.F., and Hammes, W.P. 1993. Development of mould cultures for Rohwurst manufacture. Fleischwirtschaft, 73: $327-328,331-332$.

62. Leistner, L. 1990. Mould-fermented foods: recent developments. In Food Biotechnology. Proceedings of the International Conference on Biotechnology and Food, 20-24 February 1989, Stuttgart, Germany. Vol. 4. Marcel Dekker, New York. pp. 433-441.

63. Wicklow, D.T. 1989. Fungal succession: technology transfer of ecological data. In Recent Advances in Microbial Ecology. Proceedings of the 5th International Symposium on Microbial Ecology. Edited by T. Hattori, Y. Ishida, Y. Maruyama, R.Y. Morita, and A. Uchida. Japan Scientific Societies Press, Tokyo. pp. 280-284.

64. Nout, M.J.R., Martoyuwono, T.D., Bonné, P.C.J., and Odamtten, G.T. 1992. Hibiscus leaves for the manufacture of usar, a traditional inoculum for tempe. J. Sci. Food Agric. 58: 339-346.

65. Laplace, J.M., Delgenes, J.P., Moletta, R., and Navarro, J.M. 1992. Alcoholic glucose and xylose fermentations by the coculture process-compatibility and typing of associated strains. Can. J. Microbiol. 38: $654-658$.

66. Laplace, J.M., Delgenes, J.P., Moletta, R., and Navarro, J.M. 1993. Effects of culture conditions on the co-fermentation of a glucose and xylose mixture to ethanol by a mutant of Saccharomyces diastaticus associated with 
Pichia stipitis. Appl. Microbiol. Biotechnol. 39: 760-763.

67. Pirselova, K., Smogrovicova, D., and Balaz, S. 1993. Fermentation of starch to ethanol by a co-culture of Saccharomycopsis fibuligera and Saccharomyces cerevisiae. World J. Microbiol. Biotechnol. 9: 338-341.

68. Horn, C.H., DuPreez, J.C., and Kilian, S.G. 1992. Fermentation of grain sorghum starch by co-cultivation of Schwanniomyces occidentalis and Saccharomyces cerevisiae. Bioresour. Technol. 42: 27-31.

69. Horn, C.H., DuPreez, J.C., and Kilian, S.G. 1992. Protein enrichment of grain sorghum by submerged culture of the amylolytic yeasts Schwanniomyces occidentalis and Lipomyces kononenkoae. World J. Microbiol. Biotechnol. 8: $416-422$.

70. Deshpande, M.V. 1992. Ethanol production from cellulose by coupled saccharification/fermentation using Saccharomyces cerevisiae and cellulase complex from Sclerotium rolfsii UV-8 mutant. Appl. Biochem. Biotechnol. 36: $227-234$.

71. Christakopoulos, P., Li, L.W., Kekos, D., and Macris, B.J. 1.993. Direct conversion of sorghum carbohydrates to ethanol by a mixed microbial culture. Bioresour. Technol. 45: 89-92.

72. Ohta, K., Hamada, S., and Nakamura, T. 1993. Production of high concentrations of ethanol from inulin by simultaneous saccharification and fermentation using Aspergillus niger and Saccharomyces cerevisiae. Appl. Environ. Microbiol. 59: 729-733.

73. Lee, S.-W., Yajima, M., and Tanaka, H. 1993. Use of food additives to prevent contamination during fermentation using a co-immobilized mixed culture system. J. Fermentation and Bioengin. 75: 389-391.

74. Cojho, E.H., Reis, V.M., Schenberg, A.C.G., and Dobereiner, J. 1993. Interactions of Acetobacter diazotrophicus with an amylolytic yeast in nitrogen-free batch culture. FEMS Microbiol. Lett. 106: 341-346.

75. Romanos, M.A., Scorer, C.A., and Clare, J.J. 1992. Foreign gene expression in yeast - a review. Yeast, 8: $423-488$.
76. Lang-Hinrichs, C., and Hinrichs, J. 1992. Recombinant yeasts in food and food manufacture-possibilities and perspectives. Agro-Food-Ind. Hi-Tech, 3(5): 12-18.

77. Damore, T. 1992. Improving yeast fermentation performance. J. Inst. Brew. 98: 375-382.

78. Shibuya, I., Tamura, G., Goto, E., Ishikawa, T., and Hara, S. 1992. Characteristics of koji prepared from the transformant of Aspergillus oryzae with the glucoamylase gene of Aspergillus shirousamii, and its utilization for sake-brewing. J. Ferment. Bioeng. 73: 415-417.

79. Querol, A., Barrio, E., Huerta, T., and Ramon, D. 1992 Molecular monitoring of wine fermentations conducted by active dry yeast strains. Appl. Environ. Microbiol. 58: 2948-2953.

80. Sulo, P., and Michalcakova, S. 1992. The K3 type killer strains of genus Saccharomyces for wine production. Folia Microbiol. 37: 289-294.

81. Perez-Gonzalez, J.A., Gonzalez, R., Querol, A., Sendra, J,, and Ramon, D. 1993. Construction of a recombinant wine yeast strain expressing beta- $(1,4)$-endoglucanase and its use in microvinification processes. Appl. Environ. Microbiol. 59: $2801-2806$.

82. Caldini, C., Bonomi, F., Pifferi, P.G., Lanzarini, G., and Galante, Y.M. 1994. Kinetic and immobilization studies on fungal glycosidases for aroma enhancement in wine. Enzyme Microb. Technol. 16(4): 286-291.

83. Kishimoto, M. 1994. Fermentation characteristics of hybrids between the cryophilic wine yeast Saccharomyces bayanus and the mesophilic wine yeast Saccharomyces cerevisiae. J. Ferment. Bioeng. 77(4): 432-435.

84. Wightman, J.D., Xu, X., Yorgey, B.M., Watson, B.T. Mcdaniel, M.R., Micheals, N.J., and Bakalinsky, A.T. 1992. Evaluation of genetically modified wine strains of Saccharomyces cerevisiae. Am. J. Enol. and Vitic. 43: 283-289.

85. Barnett, J.A., Payne, R.W., and Yarrow, D. 1990. Yeasts characteristics and identification. Cambridge University Press, Cambridge, U.K. 